\title{
STATUTORY BAR ON THE RIGHT TO EXERCISE A MORTGAGE UNDER THE CONDITIONS APPliCABle IN THE SLOVAK REPUbliC AND COMPARISON WITH THE LEGAL REgUlATION OF THE CZECH REPUBLIC
}

\author{
Nikola Pacalajová ${ }^{1}$, Martin Kubinec ${ }^{2}$
}

\begin{abstract}
Based on the analysis and comparison of legal regulation and existing case law, the authors present in the paper their opinion on the issue of deleting mortgage with statute-barred claim from public records (Land Registry). The Slovak legal regulation, in contrast with the Czech one, does not include an explicit provision enabling the deletion of mortgage with statute-barred claim from Land Registry. Taking into consideration the aspect of justice, the authors reached the conclusion that even without a normative platform, it is necessary to allow the mortgagor to apply to court to determine that the real estate is not mortgaged and subsequently use the court's decision as a basis for deletion. However, since the courts decide in this case, using judicial activism, knowingly contrary to the purpose and content of the institute of statutory bar, the authors consider it essential that legislation be adopted as soon as possible to regulate this situation.
\end{abstract}

\section{Keywords}

Statutory Bar, Lien, Mortgage, Right to Exercise a Mortgage, Declaratory Action

\section{Introduction}

Mortgage, as a specific type of lien charging the real estate, is currently a very frequent and effective real-right means of creating security for receivables and related civil fruits. Under the conditions applicable in the Slovak Republic, mortgage, together with the pledge charging the movable property, is regulated in Act No. 40/1964, the Civil Code as subsequently amended (hereinafter referred to as the "Civil Code" or "CC"). In principle, the Slovak de lege lata legislation regulating mortgage does not show any shortcomings

\footnotetext{
${ }^{1}$ Matej Bel University in Banská Bystrica, Komenského 20, 97401 Banská Bystrica, Slovak Republic. E-mail: nikola.pacalajova@umb.sk.

${ }^{2}$ Matej Bel University in Banská Bystrica, Komenského 20, 97401 Banská Bystrica, Slovak Republic. E-mail: martin.kubinec@umb.sk.
} 
which could significantly discourage, whether a lienee or lienor, from entering into a pledge agreement. However, this does not mean that such regulation cannot be even improved, which fact is also reflected in the context of statutory bar on right to exercise mortgage. The principle of vigilantibus iura scripta sunt, as a fundamental principle of private law, applies to mortgage as well. The Civil Code mentions the "statutory bar on a lien" and although it is a common term used in the case law of the courts ${ }^{3}$, with aim to achieve terminological correctness we will use the concept of "right to exercise the lien", or the "right to exercise the mortgage", since the statutory bar on lien is conceptually impossible, as we will comment on in more detail herein. With respect to statutory bar on the right to exercise mortgage in practice, a number of questions arise. Under the conditions applicable in the Slovak Republic, the most problematic aspect lies in the fact that the law does not provide for the extinction of this right after having been statute-barred. Based on the exhaustive enumeration of the reasons for extinction of lien (Section 151md, subsection 1 of the Civil Code) and subsequently on the nature of the institute of statutory bar, we may state that the right to exercise mortgage shall survive barring by the statute of limitations, i.e. it does not cease to exist. Following this, there is a question as to whether, and if so, in which manner, is it possible to achieve the deletion of mortgage from relevant records, i.e. the Land Registry in the Slovak Republic. ${ }^{4}$ The existence of registration of mortgage in Land Registry with statute-barred right to exercise the same has undoubtedly a negative impact on the real estate market, as well as on the legal certainty of the parties to legal relationships.

The answer to this question is not unified in Slovak theory and practice. The controversy concerns in particular whether the mortgagor may, even without an explicit provision allowing the deletion of a non-extinguished (statute-barred) right, apply to the court to determine that no mortgage exists and subsequently use such court decision as a basis for deleting mortgage from Land Registry. The doctrine also discusses the application of revolutionary decision of the Supreme Court of the Czech Republic rendered under file ref. No. 21Cdo 2185/2009 of 21 December 2010 in the Slovak Republic, with some Slovak courts having already adopted it. ${ }^{5}$

Due to the common legislative history, the Czech case law is in Slovakia generally relatively strongly accepted, and therefore it is often referred to in the decisions of Slovak courts, as is the case with the partial issue of mortgage. The Civil Code, which was adopted by the National Assembly of the Czechoslovak Socialist Republic and which is still (with many amendments thereto) applicable in the Slovak Republic, was, until 31 December 2013,

\footnotetext{
${ }^{3}$ With this respect, see, for example: Judgment of the Constitutional Court of the Slovak Republic of 8 December 2011, file ref. No. II. ÚS 250/2011 or Resolution of the Supreme Court of the Slovak Republic of 19 December 2017, file ref. No. 1Obdo / 22/2017.

${ }^{4}$ Land Registry is a geometric designation, inventory and description of real estate. Land Registry includes data on the rights to such real estate. With this respect, see: Section 1, subsection 1 of Act No. 162/1995 on Land Registry and on Registration of Ownership and Other Rights to Real Estate (Cadastre Act).

${ }^{5}$ The Supreme Court of the Czech Republic stated in this judgment: "Should the lien be statute-barred, lienor may undoubtedly succeed in invoking the statutory bar for any defence (provided by law) against the exercise of the right (claim) of lienee to satisfy a secured claim from the proceeds from realization of collateral, i.e. also in proceedings initiated by an action for determination that no lien exists."
} 
effective in the Czech Republic as well. As of 1 January 2014, the Act No. 89/2012, the Civil Code (hereinafter referred to as the "Czech Civil Code" or "CCC") became effective, representing the completion of the Czech recodification process in the field of private law. The Czech Republic followed the path of a monistic concept and the Czech Civil Code has the character of a basic private law code, as upon the effectiveness of the CCC, the Commercial Code was repealed as well. ${ }^{6}$

The Slovak Republic is behind its neighbour in this area and within the recodification of private law it reached the farthest in October 2018, when the Ministry of Justice of the Slovak Republic published a bill on its website, which should comprehensively amend the entire section of the applicable Civil Code concerning obligations (including the statutory bar regulation) (hereinafter referred to as the "Draft Amendment to the Civil Code"). ${ }^{7}$ The legal regulation of obligation relationships should be uniform for civil-law and commercial-law relationships. ${ }^{8}$ In the area of lien, however, it got ahead the Czech Republic when, in 2002, it proceeded to the reform of lien, which even became the inspiration for drafting the legal regulation of lien in the Czech Civil Code. ${ }^{9}$

Although cases of statutory bar on mortgage are relatively rare, they can be encountered in practice. The aim of this paper is to answer the question of possibility of deleting the mortgage with statute-barred claim from Land Registry, as the persistence of such registration restricts the mortgagor in exercising their property rights. The authors primarily focus on answering the question of whether a mortgagor can apply to a court to determine that no mortgage exists, in order to obtain a court decision as a basis for deleting mortgage from Land Registry.

\section{General Principles of Statutory Bar on the Right to Exercise Mortgage}

The existence of a substantive institute of the statutory bar is a consequence of the requirement of legal certainty, the purpose of which is, inter alia, to ensure that undischarged legal relationships do not persist for an unreasonable length of a period of time. At the same time, the statutory bar is an institutional enforcement of the general principle of vigilantibus iura scripta sunt in private law and is therefore intended to encourage creditors to exercise their rights in a timely manner. Since no legal definition of statutory bar exists, we must be content with a definition provided by legal doctrine. ${ }^{10}$ Marek Števček characterizes statutory bar as a legal consequence of a qualified lapse of time

\footnotetext{
${ }^{6}$ However, the Recodification Commission of the Ministry of Justice of the Czech Republic did not choose the path of complete commercialization of the Czech Civil Code, since the legal regulation of companies and cooperatives is contained in Act No. 90/2012 on Companies and Cooperatives, which entered into effect at the same time as the Czech Civil Code.

${ }^{7}$ The Draft Amendment to the Civil Code together with the explanatory memorandum is available on the website of the Ministry of Justice of the Slovak Republic: https://www.justice.gov.sk/Stranky/Ministerstvo/Aktualityobcianskeho-zakonnika.aspx.

${ }^{8}$ I.e. after the possible adoption of the Draft Amendment to the Civil Code, the entire third part of Act No. 513/1991, the Commercial Code, entitled "Commercial Obligation Relationships" should be repealed.

${ }^{9}$ Eliáš In: Hrušáková (2011).

${ }^{10}$ With this respect, compare: Section 1451 of ABGB: "Statutory bar is the loss of a right which has not been exercised within the time prescribed by law."
} 
in relation to the nature of a right in question. ${ }^{11}$ The statutory bar on given right occurs by the lapse of statutory bar period, but unlike the institute of lapse of claim, the onset of consequences of statutory bar is conditioned by pleading the limitations statute by debtor. ${ }^{12}$ The consequence of the fact that debtor is successful in invoking the statutory bar, i.e. that the court accepts pleading the limitations statute by debtor, is weakened right consisting in the loss of the claim. ${ }^{13}$ Due to loss of the claim a right becomes the so-called natural obligation (obligatio naturalis) ${ }^{14}$, thus becoming unenforceable against the will of debtor. The creditor cannot enforce their right through the courts, but debtor may continue to discharge their debt on a voluntary basis ${ }^{15}$ and such discharge will not constitute an unjust enrichment. ${ }^{16}$ Only mortgagor may succeed in invoking the statutory bar on exercise of mortgage, i.e. only the one who is the owner of the pledge and who may be directly affected by the exercise of mortgage. ${ }^{17}$ Therefore, it is not possible for the obligatory debtor under secured claim to plead effectively the limitations statute.

The time limitation of claimability of any right has two basic aspects - positive and negative. ${ }^{18}$ A positive aspect is the motivation of creditors to assert their claims in a timely manner, which is aimed in particular at reducing entropy in the exercise of rights and simplifying evidence. On the contrary, the negative aspect means weakening of possibility to exercise the right after the expiry of a certain period of time after such right has originated, as the statutory bar and the subsequent pleading the limitations statute by debtor deprives the creditor's right of a claim resulting therefrom which thus becomes unenforceable. On one hand, the enforceability of a right is an important value of the rule of law for any creditor, but on the other hand, the fulfilment of the principle of legal certainty is an important value of the rule of law for any debtor. ${ }^{19}$

Given the wording of the Civil Code which uses the phrase "statutory bar on a lien", it must first be stated that the lien as such may not be statute-barred, because it is a right in rem where there is nothing to be subject to statutory bar. ${ }^{20}$ The statutory bar on a lien is not possible in terms of concept, because a lien itself does not impose an obligation of any performance, and therefore this is a gross terminological inaccuracy on the part of the

\footnotetext{
11 Števček, Dulak, Bajánková, Fečík, Sedlačko, Tomašovič et al. (2015).

${ }^{12}$ Pleading the limitations statute is, as a plea under substantive law, regulated within the general provisions of the Code of Civil Dispute Procedure, specifically amongst the means of procedural attack, procedural defence (Section 152 of CCDP). As to the pleading the limitations statute, see, for example: Strapáč, Durana (2013).

${ }^{13}$ According to Luby (1958), a claim is a substantive component of a right and can be defined as the enforceability of a right.

${ }^{14}$ As to the origin of the term, see, for example: Frenzel (1897).

${ }^{15}$ As a result of voluntary discharge by debtor, natural obligation is converted into a regular obligation with legal effects ex tunc. See: Fekete (2016).

${ }^{16}$ Since it is a performance in compliance with the law, voluntary discharge of a natural obligation does not constitute unjust enrichment on the part of creditor and, since such discharge is regarded as the fulfilment of a debt, it cannot constitute a donation. This is expressly provided for in Section 534 of the German BGB.

${ }^{17}$ Judgment of the Constitutional Court of the Slovak Republic of 8 December 2011, file ref. No. II. ÚS 250/2011.

${ }^{18}$ Compare: Weinhold (2015).

${ }^{19}$ Compare: Judgment of the Constitutional Court of the Slovak Republic of 8 December 2011, file ref. No. II. ÚS 250/2011.

${ }^{20}$ With this respect, see: Section 100, subsection 2 of CC and Section $151 \mathrm{j}$, subsection 2 of CC.
} 
legislator. The purpose of a lien is only to secure the claim of a lienee in the event that it is not satisfied in a timely and proper manner by the obligatory debtor. Only the right of a lienee to demand satisfaction from pledge or the right to exercise the lien may be statute-barred, since it is a property right that allows performing the payment function of a lien.

These conclusions are also confirmed by wording of the Draft Amendment to the Civil Code, which in Section 105 regulates the "statutory bar on claims from lien and retention right" and not the statutory bar on lien. ${ }^{21}$ In this respect, the proposed explanatory memorandum states that, from the point of view of statutory bar, the essence of a claim from lien lies in the lienee's right to demand that the lienor suffer the exercise of the lien. ${ }^{22}$ It is interesting that the Czech legislator did not use the opportunity for clarifying terminology in the recent codification when, in Section 615 of CCC, in the same manner as the previous regulation, it mentions the "statutory bar on a lien", with explanatory memorandum expressly specifying that the lien itself (as proprietary right) is subject to statutory bar.

Related to the above mentioned is the beginning of the statutory bar period, which in case of the right to exercise mortgage (as with other types of lien) begins to run from the day when this right could be exercised for the first time. ${ }^{23}$ The right to exercise mortgage could be exercised for the first time on the day following the date of expiry of maturity period of secured receivable. ${ }^{24}$ In simple terms, we can identify the beginning of the statutory bar period with the moment when the claim arises. Therefore, we can associate the beginning of statutory bar period in mortgage with the moment when the right becomes actio nata. However, if the lien is perfected only after the due date of receivable, statutory bar period begins to run at the same time as the lien is thus perfected.

As for the length of statutory bar period, in case of a lien, whether charging the movable or immovable property, in the Slovak Republic it is a general, three-year statutory bar period. ${ }^{25}$ However, the length of statutory bar period is also determined by the rule set forth in the third sentence of Section 100, subsection 2 of the Civil Code, which reads: "Lien shall not be barred by the statute of limitations prior to a secured receivable." With this provision, the legislator emphasizes the accessory nature of the lien. A situation where, in the case of right to demand satisfaction from pledge, the general statutory bar period expires prior to a secured receivable, occurs e.g. when a receivable governed by the Commercial Code is secured. ${ }^{26}$ The general statutory bar period set forth by the Commercial Code is four years,

\footnotetext{
${ }^{21}$ See reference note No. 7 .

22 See reference note No. 7.

23 Section 101 of CC.

${ }^{24}$ With this respect, see, for example: Decision of the Supreme Court of the Czech Republic, file ref. No. 21 Cdo 1918/2005 of 25 April 2007.

${ }^{25}$ Section 101 of CC.

${ }^{26}$ Furthermore, this situation may occur, for example, due to application of the institute of acknowledgment of a debt, where the statutory bar period is 10 years from the date on which a debt has been acknowledged. With this respect, see Section 110, subsection 1 of CC in conjunction with Section 558 of CC.
} 
therefore the rule enshrined in the mentioned third sentence of Section 100, subsection 2 of CC applies to given one-year difference. ${ }^{27}$

However, the accessory nature of a lien is, when it comes to the issue of statutory bar, not absolute, because under Section 151j, subsection 2 of the Civil Code: "If a lien has not been statute-barred, lienee may satisfy their right (receivable) from pledge even if their principal (secured) receivable against debtor has been statute-barred in the meantime." The statutory bar on secured receivable does not prevent the lienee from exercising the lien. The Civil Code thus explicitly approves the possibility of exercising the lien even after the secured receivable has been statute-barred, of course only provided that the claim from lien is still existent.

The legal regulation of statutory bar on exercise of the lien is similar in the Czech Republic. The difference in case of mortgage lies in the length of statutory bar period, which is 10 years, as is the case in any right entered into public records. ${ }^{28}$ In relation to strengthening the autonomy of the will, the Czech Civil Code has also waived the mandatory nature of the provisions on statutory bar and allows the contracting parties to negotiate a different length of statutory bar period within the framework set by defined rules. ${ }^{29}$

The dual legal regulation, which still persists in the Slovak Republic, causes considerable application problems in practice, as evidenced by the question of choosing the legal regime which shall govern the statutory bar on exercise of mortgage. First of all, it should be noted that the Commercial Code does not contain a special legal regulation of the lien ${ }^{30}$, and thus the legal regulation contained in the Civil Code applies also to commercial relationships. However, mortgage is used primarily when securing a loan agreement, which is, as the so-called absolute commercial obligation relationship, governed by the Commercial Code irrespective of the nature of the parties thereto. ${ }^{31}$ Therefore, the question arises as to which legal regime shall govern the statutory bar in a lien relationship, which has the character of a subsidiary, accessory legal relationship. This question has been answered by established case law, according to which the statutory bar on a lien is governed by the Civil Code and other regulations of civil law, even if it has secured a receivable from a commercial obligation relationship, most often from a loan agreement. ${ }^{32}$

\footnotetext{
${ }^{27}$ However, Ovečková (2015) states that the application of this rule is not without problems either, given that there is a dispute as to whether the enshrined rule should also apply to a situation where the lienor and the obligatory debtor are different persons. In our opinion, the wording of the Civil Code does not suggest that when applying the rule, a distinction should be made as to whether or not a lienor is also a debtor under a secured claim, and we see no reason to deviate from the grammatical interpretation of the provision.

${ }^{28}$ Section 631 of CCC.

${ }^{29}$ In terms of these rules contained in Section 630, subsection 1 and 2 of CCC, the minimum length of limitation period is 1 year and the maximum is 15 years. At the same time, however, a shorter or longer limitation period must not be to the detriment of the weaker party, otherwise such arrangement shall not be taken into consideration. An arrangement for a shorter limitation period shall also not be taken into consideration in case of a right to performance arising out of harm to liberty, life or health or a right arising out of a wilful breach of obligations.

${ }^{30}$ Save the statutory regulation of lien charging the share in business (Section 117s of Commercial Code).

${ }^{31}$ With this respect, see: Section 261, subsection 6 of Commercial Code.

${ }^{32}$ With this respect, see, for example: Judgment of the Supreme Court of the Czech Republic of 8 February 2007, file ref. No. 21 Cdo 681/2006; Resolution of the Supreme Court of the Czech Republic of 11 July, 2013,
} 


\section{As to the Issue of Deletion of Mortgage With a Statute-Barred Claim From Land Registry}

In case of mortgage, since it is registered in Land Registry, it is necessary to distinguish two aspects, when it comes to statutory bar. The first aspect is upholding a statutory bar by a court, as a result of which the right cannot be granted. The second is the registration of mortgage in Land registry, which is independent of pleading the limitations statute. ${ }^{33}$ The right to exercise the lien does not extinguish after having been statute-barred and continues to exist; therefore there is no reason to delete it, as the deletion is carried out only for extinguished rights; this results not only from the nature of the institute of statutory bar but also from Section 151md, subsection 1 of the Civil Code, which exhaustively enumerates the reasons for extinguishment of a lien. ${ }^{34}$ There are typically two phases for perfection of a contractual mortgage - on the basis of a mortgage agreement, mortgage is only established and only upon registration in Land Registry, it is perfected, with such registration having thus a constitutive effect. On the other hand, deletion does not have such substantive effects and the extinguishment of mortgage occurs directly on the basis of certain legal facts.

However, as mortgage is registered in Land Registry, it significantly limits the mortgagor to dispose of a real estate, even though they have successfully pleaded the limitations statute before the court. ${ }^{35}$ The restriction does not only concern the alienation of real estate, but also the repeated encumbering the same, in particular for the benefit of a bank which underlies the provision of a mortgage loan by charging an unencumbered real estate with a mortgage. Therefore, it is reasonably possible to ask whether the mortgagor is entitled to obtain the deletion of mortgage from Land Registry in such situation.

The above mentioned indicates that, although the right to exercise mortgage does not cease to exist after having been statute-barred, there is still an aspect of proportionality and legal certainty (especially as regards the mortgagor who is not an obligatory debtor) as to whether the mortgagor should bear the consequences of the mortgagee's inaction, and therefore whether there is a legitimate reason for an indefinite duration of the registration of mortgage in Land Registry, which mortgage no longer contains a right to be exercised, as the persistence of such registration undoubtedly distorts the real estate market.

There is no provision in the Civil Code that would address such situation. On the other hand, the Czech Civil Code enshrined the provision of Section 618, according to which: "If a right entered in public records or in register of pledges has been statute-barred, such statute-barred right shall be deleted by the person maintaining such records or register, at the request of the person having a legal interest in the deletion." This provision directly

\footnotetext{
file ref. No. 21 Cdo 2302/2012 or Judgment of the Constitutional Court of the Slovak Republic of 8 December 2011, file ref. No. II. ÚS 250/2011.

${ }^{33}$ Land Registry serves to protect real estate rights and the data entered therein shall be valid unless proven otherwise.

${ }^{34}$ Based on mandatory nature of legal regulation of rights in rem, including the legal regulation of their extinguishment, we may state that the reasons for extinguishment of lien cannot be extended.

35 With this respect, see, for example: Lasák, Vyhnánek (2008).
} 
allows for the deletion of a non-extinguished right. ${ }^{36}$ In this respect, the Czech author Lukáš Vymazal states in his monograph that although this solution enabling the deletion of a non-extinguished right is not formally completely correct, other aspects (more socially relevant) justify such procedure. ${ }^{37}$ In relation to this, the explanatory memorandum states: "In the event of statutory bar on such right (a right which is entered in public records, author's note), a person with a legal interest therein shall be entitled to claim that the statute-barred right be deleted from public register. Right the origin of which is linked to entry in the public register shall cease to exist upon deletion from such public register."38 In our opinion, the allegation stating that the mortgage (or the right to exercise mortgage) extinguishes upon deletion from public register, is not supported by law. This right continues to exist in principle, but such academic debate is more or less pointless, as a re-entry in the public register would require a decision that such right exists. However, since an exigent legal request is required for rendering such decision, and the right to exercise mortgage is already statute-barred, mortgagee would probably fail to prove an exigent legal request.

Interestingly, the Allgemeines bürgerliches Gesetzbuch (hereinafter referred to as the "ABGB"), which directly influenced "Czech-Slovak" private law, had such situation in mind, and set forth in Section 1499: “. . . when the statutory bar period expires, obligated person may apply for deleting their obligation entered in the public books or demand a declaration that the right so far granted to beneficiary and the documents issued with this respect cease to be valid." ${ }^{39}$ At that time, the institute of statutory bar was of essentially the same construct and the right did not cease to exist upon having been statute-barred. ${ }^{40}$ However, according to ABGB, the statutory bar period was 30 years and, in the case of legal entities, even 40 years. $^{41}$

\section{Application Practice}

Only one way of deleting the statute-barred mortgage is lege artis possible, namely through the institution of waiver of one's security interest. The legal regulation allows the mortgagee to waive their security interest, that being a special reason for the extinction of lien under Section $151 \mathrm{md}$, subsection 1 (c) of CC. ${ }^{42}$ The dispute over deletion of statutebarred mortgage therefore affects only a situation in which the mortgagee is unwilling to take action aimed at deleting it. However, it cannot be expected that mortgagee will take the

\footnotetext{
${ }^{36}$ Except in case where statutory bar is acknowledged directly by the lienee, this basis will be a court decision.

37 Vymazal (2019).

${ }^{38}$ Explanatory memorandum to the Czech Civil Code. Available on the Internet: http://obcanskyzakonik.justice.cz/images/pdf/Duvodova-zprava-NOZ-konsolidovana-verze.pdf.

${ }^{39}$ With this respect, Tilsch (1911) stated: "The owner pleading the limitations must, if he wishes to defend himself against the consequences of the principle of publicity, bring an action for deletion against the registered creditor and may have the action registered."

${ }^{40}$ With this respect, see Section 1451 of ABGB.

${ }^{41}$ Section 1478 and Section 1485 of ABGB.

${ }^{42}$ Provision of Section $151 \mathrm{md}$, subsection 1(c) of CC does not prescribe either the type of legal act by which the lien may be waived or its form. However, based on the general legislation on extinguishment of obligations, specifically on Section 574 of CC, we know that there must be a written agreement between the debtor and the creditor.
} 
necessary action towards deletion of a lien. If mortgagor pleads the limitations statutes with respect to the right to exercise mortgage, the mortgagee may no longer demand satisfaction from pledge, but the mortgage remains registered in the Land Registry. However, does the persistence of this registration make sense if the mortgage can no longer be carried out against the mortgagor? This situation evokes a kind of circulus vitiosus and the legal doctrine is not uniform in answering the question whether it is possible to delete mortgage without the right to exercise the same from Land Registry, even without a normative platform for doing so.

In this context, the possibility of applying the so-called "declaratory action" according to Section 137(c) of Act No. 160/2015, the Code of Civil Dispute Procedure (hereinafter referred to as "CCDP") is discussed. An action for determination may be used to decide whether or not a right exists, where there is an exigent legal request for doing so. However, the problem arises from the fact that, since a mortgage with statute-barred right to exercise the same continues to exist as a right in rem, prayer for relief of action for a determination that no mortgage exists, has no substantive basis in law.

Nevertheless, the Supreme Court of the Czech Republic in a revolutionary decision rendered under file ref. No. 21Cdo 2185/2009 (hereinafter referred to as the "SCCR Decision") even before the entry into effect of the new Czech Civil Code, ruled that: "Any lienor may defend themselves against the lienee's right to satisfy a secured receivable from proceeds from realization of pledge, while using not only defence (as prescribed by the law) against the lienee's petition for realization of pledge, but also through an action to determine that no lien exists (e.g. by determining that the thing is not encumbered by the lien), if there is an exigent legal request for such determination [Section 80(c) of Czech Civil Procedure Code] (currently, this is provision of Section 137(c) of CCDP, the authors' note)." 43

In this case, the Supreme Court of the Czech Republic ruled as a court of appeal, quashed the decision of the Regional Court in Brno and returned the case to the same for conducting further proceedings. The Regional Court in Brno agreed with the opinion of the Žd'ár nad Sázavou District Court, considering that the statutory bar on a lien or the statutory bar on a secured receivable cannot be a reason for extinction of a lien, when "pleading the limitations statute may be relevant in proceedings on action for performance, however, not on declaratory action", and the lienee's statute-barred right "does not cease to exist even after rejecting final and decisive decision of the court" and is "deprived of the so-called claim and it is a so-called natural right". ${ }^{44}$

However, the Supreme Court of the Czech Republic stated vis-à-vis that although in general the statute-barred right persists as the so-called natural obligation, such conclusion cannot be applied to a lien. If a lienor reasonably pleaded the limitations statute of lien, it is not possible to successfully deduce the so-called natural obligation, consisting in the possibility of satisfying a secured receivable from the proceeds from realization of a pledge. The Supreme Court further stated that realization of pledge upon petition filed by lienee may no longer be executed here and the voluntary discharge of the right (claim)

\footnotetext{
43 Judgment of the Supreme Court of the Czech Republic, file ref. No. 21 Cdo 2185/2009 of 21 December 2010.

44 Judgment of Žd’ár nad Sázavou District Court, file ref. No. 11 C 217/2005.
} 
to satisfy a secured receivable from the proceeds from realization of pledge by lienor is not conceptually possible; in contrast to the obligation legal relationships, a "statute-barred debt" cannot be therefore, in this case, due to its nature, accepted. ${ }^{45}$

We believe that there is a terminological problem here, which we mention herein above. We will briefly remind that both the Civil Code and the Czech Civil Code use the term "statutory bar on lien". Rights in rem are generally not subject to statutory bar, which also applies to lien as a proprietary right in re aliena. ${ }^{46}$ However, the statutory bar on claims relating to proprietary rights in re aliena is permitted. Therefore, with respect to a lien, we cannot say that it survives itself in the form of a natural obligation. After having being subject to statutory bar, only a right to exercise a lien survives in the form of natural obligation.

However, the cited SCCR Decision only mentions the statutory bar on lien and in fact correctly states that the lien cannot exist in the form of a natural obligation, but does not comment on the right to exercise the lien. In our opinion, the fact that voluntary performance is not conceptually possible with a lien does not change the fact that the right to exercise the lien persists in a weakened form. Although it can be acknowledged that the SCCR Decision seeks to resolve the injustice consisting in persistence of registration of mortgage in Land Registry (or in other records, or possession of a pledge by mortgagor) even after expiry of the statutory bar period, it incorrectly evaluates the legal grounds since the right to exercise the mortgage does not cease to exist after having been statute-barred. Therefore, we do not consider its reasoning to be capable of justifying the admissibility of the action for determination that no mortgage exists. This decision has also been criticized by Czech legal doctrine. ${ }^{47}$

However, the SCCR Decision was also adopted by the Slovak courts, the following decision may serve as an example thereof: decision of the Regional Court in Trnava rendered under file ref. No. 23Co/55/2016 (hereinafter referred to as the "KST Decision"). ${ }^{48}$ In the present case, the Regional Court in Trnava upheld the decision of Galanta District Court (hereinafter referred to as the "District Court"), which ruled that immovable property was not encumbered by a mortgage for the benefit of the defendant, as it concluded that the petitioner could not be fairly demanded to continue to suffer the existence of a mortgage. ${ }^{49}$ It assumed that the mortgage existed as such, but since it was statute-barred, the defendant could not exercise it and therefore could not obtain satisfaction of his claim by realizing the collateral. According to the District Court, the petitioner established the existence of an exigent legal request for her declaratory action, on the ground that a judicial decision was the only legal remedy in view of the petitioner's current legal position. The District Court further stated in the reasoning that the court's duty is to provide legal protection to legitimate rights and obligations, while it must interpret and apply the law not only in terms of its grammatical content, because the court is not absolutely bound by the literal

\footnotetext{
${ }^{45}$ See reference note No. 44.

${ }^{46}$ Fekete (2017).

${ }^{47}$ With this respect, see: Tintera (2012).

48 Judgment of the Regional Court in Trnava, file ref. No. 23Co / 55/2016 of 17 July 2017.

49 Judgment of Galanta District Court, file ref. No. 15C /282/2015 of 20 October 2015.
} 
wording of legal provisions; to the contrary, the court shall apply such statutory provisions while taking into consideration also their purpose and, in cases where the purpose of the law requires so, the court is even obliged to deviate from the content of legal rules resulting only from their simple grammatical interpretation. ${ }^{50}$ The District Court did not rely on the SCCR Decision at all, but the Regional Court in Trnava, as the court of appeal, proactively referred to it in its reasoning.

In our opinion, the justification for upholding the declaratory action was theoretically more correct with the District Court than the Supreme Court of the Czech Republic, or the Regional Court in the part in which it referred to the SCCR Decision. The Supreme Court of the Czech Republic justified its decision to allow pleading the limitations statute by means of an action for a determination that no mortgage exists as follows: if a mortgagor pleaded the limitations statute of the mortgage, a natural obligation cannot be successfully inferred here. In contrast, the District Court ruled in favour of the defendant that the law provides for the specific reasons for extinguishment of a lien and at the same time acknowledged that the law does not resolve the legal situation being merits of the dispute. District Court therefore acknowledged the absence of legislation to resolve the situation of persistent registration, which it resolved through the so-called judicial creation of law or judicial activism.

The completion of the legislation comes where a teleological interpretation of the law is not sufficient, i.e. an interpretation taking into consideration the purpose and goal of the legal rule. In this particular case, however, this was not the so-called legally immanent completion of the law based on the application of the principle of analogy, but the completion of the law which is beyond the law. ${ }^{51}$ When filling the gap in the law, the so-called external principle, which is to invoke justice, has been used there. ${ }^{52}$

We will also point out the decision of the Constitutional Court of the Slovak Republic, which, with respect to the instruments for filling gaps in the law, stated: "This is done primarily by analogy... However, reference to general principles inherent in the constitutional order, principles of justice, etc. is not excluded either." ${ }^{53}$ Former Constitutional Judge of the Slovak Republic Ján Drgonec stated that from the point of view of the requirement of legal certainty, it is important to determine the rules which the judiciary must follow when completing the law so as not to deny the content and purpose of the law. ${ }^{54}$ The judge must assume that if the matter were to be heard by the legislator, the latter would create the legal rule applicable to the case. ${ }^{55}$

We can state that, given the existence of the principle of prohibition of denial of justice (prohibition of denegatio justitiae) $^{56}$, the judge must in any case assume the ad hoc role

\footnotetext{
${ }^{50}$ With respect to this reasoning, compare e.g. decisions of the Constitutional Court of the Slovak Republic under file ref. No. III. ÚS 271/2011 and under file ref. No. I. ÚS 192/2015).

${ }^{51}$ Compare: Schlosser. In: Večeřa et al. (2009), p. 197-198.

${ }^{52}$ With this respect, compare: Barak (2005), p. 71-72.

${ }^{53}$ Judgment of the Constitutional Court of the Slovak Republic of 3 September 2015, file ref. No. II. ÚS 46/2015.

${ }^{54}$ Drgonec (2008).

${ }^{55}$ Kelsen (1949).

${ }^{56}$ As to the principle, see more in, for example: Svák (1993).
} 
of the legislator and complete the law. ${ }^{57}$ The same was also assessed in the present case where the District Court held that the petitioner could not be fairly required to continue to suffer the existence of a mortgage, since the existence of that right, which is in itself without there being any real chance of enforcing it somewhen in the future, unreasonably interferes with the exercise of her fundamental rights and freedoms.

Given that the prayer for relief of an action for determination of non-existence of a lien has no substantive or procedural basis in law, in the present case it is judicial activism which, in our view, to the contrary, may cause legal uncertainty. In applying the law, it is necessary to strive for a balance between justice and legal certainty. In this case, in our opinion, this is not a typical completion of the law, because the judge not only goes against the rigid wording of the law, but also denies the essence of the institute of statutory bar. However, we are aware that there is no other way to resolve the unjust situation of the mortgagor so far, and therefore we must come to terms with such practice until appropriate legislation is adopted, but the use of judicial activism must be duly justified in each case.

However, we consider it necessary to introduce a more radical opinion held by the authors Marek Valachovič and Marek Perdík; according to mentioned authors a decision by which a court upholds the statutory bar on the exercise of a lien is not de lege lata the basis for deleting a statute-barred lien from Land Registry. ${ }^{58}$ They state that under applicable legislation, the only constitutionally compliant interpretation of this situation is the assertion alleging that a final and decisive court decision upholding the statutory bar on the exercise of lien will change the lien, upon which fact the Land Registry could enter a record into the section "C" of certificate of ownership (encumbrances), specifying that the exercise of the right with respect to a specific receivable is statute-barred.

\section{Conclusion}

Given that in the case of mortgage, the pledge is real estate, it can be assumed that the secured receivable is of a higher value and the mortgagee will develop an active approach to assert their claims. Although cases of statutory bar on the right to exercise mortgage are rare, they raise all the more problems in practice. In principle, it is impossible for the legislator, at the time of drafting the legislation, to predict all the relationships that may arise in society in a given area. The situation of the lack of legal regulation means an authorization for the judge to create the law inter partes, in a way that would not deny the purpose and content of the law.

In our view, the legislative vacuum that has arisen in the issue of statutory bar on claim from mortgage cannot be resolved in a sustainable way through judicial activism. According to the current decision-making practice of the courts, the aspect of justice is not in balance with maintaining the purpose and content of the institute of statutory bar. We therefore consider it essential that legislation be adopted as soon as possible to regulate the situation. The statutory bar on the right to exercise mortgage is not a reason for extinguishment of a mortgage, while the right to exercise mortgage survives as a natural obligation. The

\footnotetext{
${ }^{57}$ Compare: art. 2(1) and art. 4(2) of CCDP.

${ }^{58}$ See: Valachovič, Perdík (2019), p. 17-18.
} 
absence of legal regulation was aptly commented on by the Czech author Baudyš, who literally stated: "Today's concept, as well as the concept envisaged by the substantive intent of the new Civil Code, is forcing the courts to deliberately deceive. According to this concept, the court must declare on behalf of the Republic that the statute-barred right is not existent, even though everyone knows that the statute-barred right exists, however in a weakened form." $" 59$

The forthcoming reform of the Civil Code offers opportunity for legislation to address this issue. The Draft Amendment to the Civil Code was inspired by the Czech Civil Code and addresses this issue in Section 114h, according to which: "If the right from which the statute-barred claim arises is entered in public records or register, it may be deleted on the basis of a court decision that no such right exists." ${ }^{60}$ With this respect, the explanatory memorandum states: "Despite the fact that justified pleading the limitations statute does not result in the actual extinguishment of the right or statute-barred claim, for purposes of legal certainty, the obligated person, while using a declaratory action, is entitled to demand a determination that the pledge is not encumbered by a lien, whereupon the relevant right may be deleted from the public records or register."

We approve that the Recodification Commission, which is behind the Draft Amendment to the Civil Code, is trying to solve this serious problem of application practice, but it is still an unsystematic, even unconstitutional way of changing the already existing right of lienee, who disposes of such right even with statute-barred claim, to lapsed right. We perceive the proposed regulation only as a kind of support point on which the court will be able to rely, but it will still have to decide contrary to the essence of the institute of statutory bar. However, after the possible effectiveness of the Draft Amendment to the Civil Code, it will at least have a statutory authorization to do so. In order for a court with a clear conscience to decide that the statute-barred right (claim) is not existent, it would be necessary to amend the provision of Section $151 \mathrm{md}$ of the Civil Code, which exhaustively enumerates the reasons for extinguishment of a lien.

In case of a lien, a possible solution is offered by return to the concept of statutory bar which Slovak private law knew before the first codification of civil law ${ }^{61}$ and which regulated also a statutory bar whereupon a right ceases to exist (praecsriptio extinctiva) ${ }^{62}$

\footnotetext{
59 Baudyš (2002).

${ }^{60}$ Given the correctness of the terminology introduced by the Draft Amendment to the Civil Code, following wording would be more appropriate “...that no such claim exists”. According to Section 100 of the Draft Amendment to the Civil Code, the right to demand performance from an obligation (claim) is subject to statutory bar, with respect to which the explanatory memorandum states: "Unlike the previous regulation, the Civil Code is based on the generally accepted rule that not a right as such, but a legal claim is subject to statutory bar (or as a result of passage of time)."

61 Act No. 141/1950, the Civil Code.

${ }^{62}$ Fekete (2017).
} 


\section{References}

Barak, A. (2005). Purposive interpretation in law. Princeton: Princeton university press. Baudyš, P. (2002). Promlčení - oslabení nebo zánik práva? Právní rozhledy, 10(7), 328-330.

Drgonec, J. (2008). Súdna tvorba práva ako prostriedok uplatnenia zákona, zabezpečenia spravodlivosti a právnej istoty. Justičná revue, 60(5), 711-727.

Eliáš, K. (2011). Inspirační síla Všeobecného zákoníku Občanského v návrhu Občanského zákoníku pro Českou republiku. In Hrušáková, M. et al. 200 let ABGB. Od kodifikace k rekodifikaci českého občanského práva. Př́ibram: Právnická fakulta Univerzity Palackého v Olomouci.

Fekete, I. (2016). Naturálne obligácie a ich právne účinky. Košické dni súkromného práva I, 70-87.

Fekete, I. (2017). Občiansky zákonník. Velký komentár. Žilina: Eurokódex.

Frenzel, G. (1897). Über die Entstehung des römischen Rechtsbegriffs naturalis obligatio. Leipzig: Breitkopf und Hertel.

Judgment of Galanta District Court, file ref. no. 15C /282/2015 of 20 October 2015.

Judgment of the Constitutional Court of the Slovak Republic of 3 September 2015, file ref. no. II. ÚS 46/2015.

Judgment of the Constitutional Court of the Slovak Republic of 8 December 2011, file ref. no. II. ÚS 250/2011.

Judgment of the Constitutional Court of the Slovak Republic of 8 December 2011, file ref. no. II. ÚS 250/2011.

Judgment of the Regional Court in Trnava of 17 July 2017, file ref. No. 23Co / 55/2016.

Judgment of the Supreme Court of the Czech Republic of 8 February 2007, file ref. no. 21 Cdo 681/2006.

Judgment of the Supreme Court of the Czech Republic of 21 December 2010, file ref. no. 21 Cdo 2185/2009.

Judgment of Žd'ár nad Sázavou District Court, file ref. no. 11 C 217/2005.

Kelsen, H. (1949). General Theory of Law and State. Cambridge: Harvard University Press.

Lasák, J., Vyhnánek, L. (2008). Nesnesitelná těžkost existence promlčených zástavních práv aneb první pokus o výkřik. Právní rozhledy, 16(1), 22-27.

Luby, Š. (1958). Občianskoprávny nárok. Bratislava: právnické štúdie.

Ovečková, O. (2015). Premlčanie v obchodnom práve. Bratislava: Wolters Kluwer.

Resolution of the Supreme Court of the Czech Republic of 11 July, 2013, file ref. no. 21 Cdo 2302/2012.

Števček, M., Dulak, A., Bajánková, H., Fečík, M., Sedlačko, F., Tomašovič, M. et al. (2015). Občiansky zákonník I. § 1-450. Praha: C. H. Beck.

Strapáč, P., Ďurana, M. (2013). Námietka premlčania a rozpor s dobrými mravmi. Bulletin slovenskej advokácie, 19(4), 14-22.

Svák, J. (1993). Denegatio iustitiae (odmietnutie spravodlivosti). Justičná revue, 45(6), $1-14$.

The Act No. 160/2015 Coll., the Code of Civil Dispute Procedure as subsequently amended. 
The Act No. 162/1995 on Land Registry and on Registration of Ownership and Other Rights to Real Estate (Cadastre Act) as subsequently amended.

The Act No. 40/1964 Coll., the Civil Code as subsequently amended.

The Act No. 513/1991 Coll., the Commercial Code as subsequently amended.

The Act No. 89/2012 Coll., the Civil Code as subsequently amended.

The Ministry of Justice of the Slovak Republic. (2018). The draft bill and the explanatory memorandum to the proposed amendment to the Civil Code. Retrieved October, 10, 2020 from https://www.justice.gov.sk/Stranky/Ministerstvo/Aktuality-obcianskeho-zakonnika. aspx.

Tilsch, E. (1911). Právo zástavní. Praha: Všehrd.

Tintěra, T. (2012). Otazníky nad promlčením zástavního práva. Právní fórum, 8(12), 334-337.

Valachovič, M., Perdík, M. (2019). Niekolko poznámok k výkonu záložného práva a jeho premlčaniu (2. čast'). Bulletin slovenskej advokácie, 25(1-2), 12-20.

Večeřa, M. et al. (2009). Teória práva (3.). Bratislava: Eurokódex.

Vymazal, L. (2019). Zástavní právo (3.). Praha: Wolters Kluwer.

Weinhold, D. (2015). Promlčení a prekluze v soukromém právu. Praha: C. H. Beck. 